\title{
The Foreigner, the Musicians' Union, and the State in 1920s Australia: A Nexus of Conflict
}

\author{
KAY DREYFUS
}

In February 1929, the Musicians' Union of Australia (MUA) introduced an amendment to rule 7d of its conditions of admission to membership which articulated a complete embargo on foreign musicians for a twelve month period. ${ }^{1}$ Ostensibly linked to the unemployment resulting from the introduction of sound films, it was in fact a response to two specific events: an application for membership from four musicians in an orchestra of Italians that had been offered a year's employment under contract by the Hoyts theater chain from March 1928, and a challenge to the registration of new rules affecting Australian musicians in working with foreigners, heard in the Federal Court of Conciliation and Arbitration on February 22, 1929.

The embargo was renewed annually until, in 1935, a voting mechanism was introduced for the admission of non-naturalized, non-British applicants which effectively allowed the Union to exclude all preand post-war refugee musicians, displaced persons, and other immigrants from membership until they had achieved naturalization after the regulatory five-year residence period, ${ }^{2}$ a mechanism that lasted until the mid-1950's.

This article examines the development of MUA policy on foreign musicians through the 1920s, showing how this initially benevolent association turned into an obstructionist oligarchy whose purpose became, amongst other things, to prevent foreign musicians from ever obtaining work in Australia.

Rhetorically and at points of public interface with external organizations-government departments, officials of the arbitration court, overseas unions and the press - the MUA maintained a distinction between musicians who came to the country "under contract" and so-called "free-lance" musicians, who entered as individuals in free and equal competition with resident musicians. Although frequently blurred in practicethe ultimate objective of a total ban was the same in both cases - the distinction is an important one as it determined the arena of action and delimited the extent and character of the Union's control over the entry of foreign musicians and their reception. The entrepreneurial practice of importing musicians under contract was primarily disputed and negotiated publicly with erstwhile employers; applications from individual musicians, however, were dealt with internally by Union officials. Accountability varied in each situation.

I argue that the issue of the importation of foreign bands or contracted foreign musicians was situated at the nexus of a conflict of interest between the Musicians' Union on the one hand and various cultural entrepreneurs on the other, with entrepreneurs intent on importing talent from overseas to satisfy what they claimed was a public demand for quality or novelty, and the Union determined to fill all positions with Australian musicians, even though case after case suggests that the supply of local talent was neither sufficient nor as capable.

\footnotetext{
${ }^{1}$ The resolution read, "That no foreign musician be admitted to this Union for at least twelve months when the position may again be reviewed.” NSW District Minute Book 1926-1930, p. 287, Musicians' Union of Australia, Noel Butlin Archive Centre, Australian National University, Canberra (MUA NBAC) [Series] T7/1/8.

${ }^{2}$ Michelle Langfield, More People Imperative: Immigration to Australia, 1901-39, National Archives of Australia Guide 7 ([Canberra]: Commonwealth of Australia, 1999), 211. The Victoria District resolved, 12 January 1928, that "no foreigners [sic] be admitted as a member of this district unless and until such foreigner has become a naturalised British subject." NSW District Minute Book 1926-1930, p. 143, MUA NBAC T7/1/8.
} 
Policy took shape in a series of dialectic encounters between the Union and entrepreneurs within the institutional framework of the State-sponsored conciliation and arbitration system. The system was highly bureaucratic, with a process of regulatory rule-making that extended downwards from government through State and Federal tribunals to the registered organizations (employer associations and unions), then upwards again through an arduous process of negotiated settlement and award making. A discussion of the evolution of the MUA's policy on foreign musicians must, therefore, take cognizance of the ways in which the union itself was shaped by its participation in the arbitration process. It must consider how a small cohort of union officials was enabled to usurp the authority of the system in order to counter the real or imagined threat of competitive foreign labor through its application or misapplication of discretionary admission clauses in the legislation.

It is in the treatment of individuals that arguments about equity, fairness, and the protection of Australian jobs become tinged with darker elements of bigotry and narrow-mindedness. The Union's attitude towards foreign musicians was driven, and certainly sanctioned, by the racist sentiments of an all-White, allBritish Australia as expressed in the Immigration Restriction Act of 1901, the so-called "White Australia Policy," which the Union formally endorsed in its revised rule book of 1925 . $^{3}$ Characteristically, MUA rhetoric attached itself to popular causes as a means of strengthening its appeal. Hence, in the mid to late 1920s prejudicial aspects of popular concern over Italian migration fortuitously provided a context for political action.

Decisions made in the 1920s may be seen as exerting a profound (and arguably detrimental) influence on the development of musical culture in Australia for several decades, not to mention their impact on the lives of individuals already traumatized by events in Europe in the key decades of refugee migration that preceded and followed the Second World War.

Three pieces of legislation form the backdrop to this discussion. The Commonwealth Conciliation and Arbitration Act of 1904 established the institutional framework within which the issues of imported bands and foreign musicians were disputed, debated, and resolved. The Immigration Restriction Act of 1901 provided an ideological underpinning for the Union's attitudes towards non-British musicians. The amendments to the latter Act contained in the Contract Immigrants Act (1905) served as the basis of the Union's appeal for protective legislation and also for the government's introduction, in July 1928, of a form of application to control the entry of foreign musicians under contract.

Within the tiny literature on industrial relations in the Australian music industry, the Union's validation of its embargo on foreign musicians from the end of the 1920s by reference to job losses resulting from the introduction of sound film technology is accepted. ${ }^{4}$ This latter event was certainly catastrophic, and a catalyst for and rationalization of the final stage of the hardening of policy, but it was not the basis for the development of that policy, which, I argue, had begun in the previous decade.

Australia turned inwards in the decades following the First World War, which triggered a resurgence of pro-British nationalistic sentiment allied to strong anti-German feelings that became a widespread xenophobia and opposition to "foreigners." In April 1918, acting on an initiative from its New South Wales (NSW) District, the MUA undertook a purge of its membership. District Secretaries were instructed to

\footnotetext{
${ }^{3}$ A resolution advocating the formal endorsement of the policy was introduced at Federal Conference in 1923, apparently in response to an application from a colored musician. Minutes, MUA NBAC E156/6/2, p. 7.

${ }^{4}$ See Bronwen Arthur, “'Ban the Talkies!' Sound Film and the Musicians' Union of Australia 1927-1932," Context 13 (Winter 1997): 55 and her entry on "Industrial Relations," in Currency Companion to Music and Dance in Australia, eds. John Whiteoak and Aline Scott-Maxwell (Strawberry Hills, NSW: Currency Press, 2003), 348.
} 
suspend "members who are or who have been at any time subjects of a nation at war with the King," moving at once against all known members and enquiring into doubtful names. In November of the same year, at the Union's federal conference, the meeting was informed that approaches had been made to "certain members of the Federal Parliament," asking them to influence the Ministers concerned to repatriate all alien internee musicians at the end of the war: "In the concentration camps in N.S.W.," reported the Secretary (Alfred O'Brien), "there are hundreds of musicians, who having little else to do, have kept in good practice and if they are allowed to remain in Australia, will be a very serious menace to our community.",

Though the records do not show the impact of these early resolutions, several trends can be extrapolated which were prevalent throughout these formative years of MUA policy regarding foreigners: a desire to secure State endorsement of Union resolutions, an exaggerated and probably unrealistic representation of competition and, concealed in this case behind a façade of patriotic nationalism, an ideologically driven agenda aimed at creating a normative membership that was white, British, and male.

As His Honor Chief Judge Dethridge of the Commonwealth Court of Conciliation and Arbitration observed in February 1929, the labor market in music in Australia is, more than most others, "subject to excessive importation of competitive wage-earners." Within the music industry, the issue of the importation of foreign bands or contracted foreign musicians became a "frontier of control," ${ }^{8}$ as entrepreneurs resisted pressures from the Musicians' Union (representing the profession) to employ only Australian musicians and Union members. The employers asserted commercial competitiveness, popular taste, and an inadequate local supply. The union countered with various arguments, but the basic issue was the difference between a "preentry closed shop," in which initial employment must be preceded by membership of the requisite union and the union thus has almost complete control of the labor supply, and the "post-entry closed shop," which allows the employment of individuals - as in the case of foreign musicians - subject to them joining the union after their engagement, a situation which removes the control of the supply of labor from the union. ${ }^{9}$ The importation and employment of foreign musicians thus emerged as a site of "opposition of interest between those who manage and those who are managed." 10 The issue was not one of numbers but of principle, since "the right to freely contract is ... a direct threat to the interests of organised labour." 11

\section{Arbitration and Rule-making: A State-sponsored Institutional Framework}

Industrial relations in 20th century Australia were governed by the Commonwealth Court of Conciliation and Arbitration, a State-regulated system established under legislation passed by the Federal Parliament in 1904 that provided for the compulsory conciliation and arbitration of industrial disputes. ${ }^{12}$

\footnotetext{
${ }^{5}$ NSW District Minute Book 1911-1918, p. 358 and inserted Notice of the Annual Meeting of the MUA NSW District, 15 April 1918, MUA NBAC T7/1/5.

${ }^{6}$ Secretary's Report to the 1918 Federal Conference of the MUA, Minutes, MUA NBAC E156/6/1.

${ }^{7}$ Murray M. Stewart ed., Commonwealth Arbitration Reports (CAR) Vol. 27 (1928-29), (Melbourne: The Law Book Company of Australasia Ltd.), 1142.

${ }^{8}$ The phrase is cited in Stephen J. Deery and David H. Plowman, Australian Industrial Relations, 3rd ed. (Sydney: McGraw-Hill Book Company Australia, 1991), 44 and n. 32.

${ }^{9}$ Richard Mitchell and Stuart Rosewarne, "Individual Rights and the Law in Australian Industrial Relations," in Power, Conflict and Control in Australian Trade Unions, ed. Kathryn Cole (Ringwood: Penguin Books, 1982), 194.

${ }^{10}$ Deery and Plowman, 43.

${ }^{11}$ Mitchell and Rosewarne, 208.

${ }^{12}$ A copy of the Act may be found at

http://www.aph.gov.au/library/INTGUIDE/LAW/docs/CommonwealthConciliationandArbitrationAct1904.pdf, accessed August 2008. For a discussion of the distinctive features of the Australian system and a comparison with those of the USA and Britain, see Richard Mitchell, "State Systems of Conciliation and Arbitration: The Legal Origins of the Australasian Model," in Foundations of Arbitration: The Origins and Effects of State Compulsory Arbitration 1890-1914, eds. Stuart Macintyre and Richard Mitchell (Melbourne: Oxford University Press, 1989), 74-82.
} 
Within a two-tiered institutional framework, one Federal and six State tribunals were invested with powers to obtain control of disputes and enforce decisions ("Awards") on the disputants. The process involved a threeway dialogue between employer, union (representing the employees), and the officials of the court. It was possible for unions to negotiate agreements with employers outside arbitration but, as Macintyre and Mitchell affirm (pp. 1-2), such external negotiations were colored by the knowledge that the system was available in the event of an agreement not being reached.

Although "industrial arbitration" meant "the formal systems of state regulation of industrial disputes in Australia," 13 the process was informed by high-minded liberal notions in which partnership replaced confrontation and disputes were settled "through legal agency, according not to legal right but according to equity and fairness." 14 In particular, the system was seen as offering protection to the working man through registered unions, challenging the employers' view that they were "able to do as they pleased with men simply because they paid them wages."15

The arbitration system "encouraged changes in the structure and nature of unionism itself"; 16 given that "the creation of arbitration coincided with the mobilization of workers and employers, [it] helped to shape their organizational forms [my emphasis]." 17 The top officials of a Union acquired the authority of "lay advocates," $" 18$ since the Commonwealth Conciliation and Arbitration Act provided for and the Court generally favored representation by an officer of an organization in proceedings requiring knowledge of the facts of the industry in dispute. For example, the General Secretary of the MUA, assisted by the Federal President or another nominated delegate, would routinely act as union representative in federal arbitration cases and interstate negotiations and disputes. State secretaries had parallel responsibilities under State arbitration legislation.

Historians have argued, however, that the establishment of tribunals is only one of two key elements of the Australian model, the other being the provision for the registration and regulation of trade unions. As MUA General Secretary Cecil Trevelyan explained to his English counterpart, under the Arbitration Act, "Unions ... have to register before the Court recognizes them ... the Court can only bind the Union and Respondents, [namely] employers who have been cited by having the log of claims served on them and [who have been summoned to] the hearing ... The [Act] throws its cloak over both sides protecting their individual interests and compelling observance of the Award ... Both sides have obligations which can be pressed." 19 Since the system was based on collective bargaining, "Such regulation was perceived from the beginning to be integral to the purposes of the compulsory arbitration systems, which required the incorporation of unions to act as representative bodies for large groups of employees (or employers) and to supervise and enforce the award-making process." 20

Registration of unions compelled employer recognition of union interests and bargaining status and incorporated them into a legislative framework of entitlement that included preferred employment for union members, protection from discrimination, and monopoly of organization. ${ }^{21}$ It provided legal support for a

\footnotetext{
${ }^{13}$ Stuart Macintyre and Richard Mitchell, "Introduction," in Macintyre and Mitchell, 6.

${ }^{14}$ Mitchell, "State Systems," 96.

${ }^{15}$ Bede Healey, Federal Arbitration in Australia: An Historical Outline (Melbourne: Georgian House 1972), 11.

${ }^{16}$ Ray Markey, "Trade Unions, the Labor Party and the Introduction of Arbitration in New South Wales and the Commonwealth," in Macintyre and Mitchell, 170.

${ }^{17}$ Macintyre and Mitchell, "Introduction," 13.

${ }^{18}$ The term is from Orwell De R. Foenander, Trade Unionism in Australia: Some Aspects (Australia: The Law Book Co of Australasia, 1962), 20 and n.6.

${ }^{19}$ Letter, Trevelyan to F. Dambman, General Secretary, (British) Musicians' Union, 25 January 1935, MUA NBAC E156/2/4(i).

${ }^{20}$ Mitchell, "State Systems," 91.

${ }^{21}$ Macintyre and Mitchell, "Introduction," 16.
} 
union's internal system of regulation, both its structures and its objectives, ${ }^{22}$ since in order to be able to function efficiently within the system, unions needed to be able to discipline and control their membership. ${ }^{23}$ Because registration ensured the survival of a union irrespective of its numerical size and industrial power, ${ }^{24}$ the MUA was able to hold its own against the major entrepreneurs, who gained commercial muscle in the 1920s through takeovers and merging of interests, ${ }^{25}$ and later to survive the vicissitudes of the depression years.

Registration also obliged the union to develop a set of internal rules to specify, amongst other things, its objectives and the conditions and eligibility for membership. ${ }^{26}$ Under the Union's new rule 93a (added to the rule book of 1927), any State District could petition the Federal Council to make or frame any new rule or rescind, vary, or alter any existing rule. Nonetheless, a rule was not binding until registered by the Industrial Registrar, an officer of the Court of Conciliation and Arbitration, who determined its compliance with the requirements of the Act and the law.

The progress of a new rule from resolution to registration and formal incorporation was a lengthy and complex one, involving as it did a process of internal consultation, of analysis and review by the Union's solicitors ${ }^{27}$ and review and approval by the Registrar, with the possibility of amendment at each stage. For this reason one needs to consider when a rule was proposed rather than when it was registered when mapping causality, since the procedure of formulation, consultation, legal review, amendment and registration could take several years. ${ }^{28}$

Alteration of the rules to make them non-compliant, failure to bona fide observe them or judgment that "the rules ... or their administration do not provide reasonable facilities for the admission of new members or impose unreasonable conditions upon the continuance of their membership or are in any way tyrannical or oppressive" were all grounds for non-registration or cancellation of registration under Schedule 60c of the Act.

This Federal requirement was replicated within the individual States of the Commonwealth since, in order to be able to function within the respective State system (for intra-state disputes), Districts of the MUA registered independently of the federal body. State registration created a separate and distinct legal entity which could and did formulate and register its own rules. Cockburn and Yerbury note, in their discussion of the problems of multiple registration, that

there are often differences in rules, particularly the rules governing who is eligible for membership, and invalidities arise as, for example, when someone who can be a member of the state union cannot be a member of the state branch of the federal organisation, yet votes in State-branch matters, or participates in the election of State-branch officers who then make decisions within the federal union. ${ }^{29}$

\footnotetext{
${ }^{22}$ Mitchell, "State Systems," 91.

${ }^{23}$ Richard Mitchell and Esther Stern, "The Compulsory Arbitration Model of Industrial Dispute Settlement: An Outline of Legal Developments," in Macintyre and Mitchell, 108.

${ }^{24}$ Deery and Plowman, 251.

25 "It was in the 1920s that the independent (usually suburban) cinema owner was deliberately squeezed out of business by the two large exhibition chains [Hoyts and Union Theatres]... ." Diane Collins, Hollywood Down Under: Australians at the Movies 1896 to the Present Day (North Ryde: Angus \& Robertson, 1987), 116.

${ }^{26}$ Raj Jadeja, Parties to the Award (Canberra: Noel Butlin Archives Centre, Research School of Social Sciences, The Australian National University, 1994), 4 and n. 23. Schedule B of the Commonwealth Conciliation and Arbitration Act required the keeping of a register of members and the provision of rules governing "the times when, terms on which, persons may become, or cease to be members of the association...."

${ }^{27}$ Legal opinions on the rule revisions that took place in the 1920s may be found at MUA NBAC E156/8/7.

${ }^{28}$ Margin dates in the rule books give the dates of registration.

${ }^{29}$ M.R. Cockburn and D. Yerbury, "The Federal/State Framework of Australian Industrial Relations," in Power, Conflict and Control in Australian Trade Unions, ed. Kathryn Cole (Ringwood: Penguin Books, 1982), 62.
} 
The MUA registered federally as a "party to the award" in 1911. In a series of letters written to colleagues in various overseas unions, Cecil Trevelyan, the long-serving General Secretary of the MUA, ${ }^{30}$ summarized the features of the Australian system and reflected on the Union's experience of its merits and demerits:

The Federal Arbitration Court can not deal with any dispute that is not interstate, i.e. it must cover at least two States. In our industry Messrs J. C. Williamson [the largest theatrical entrepreneur] show in every State, as do Union Theatres and Hoyts (both pictures), B. J. Fuller (Theatrical) etc and as our Union is in every State the Federal Award is most useful to us ... Each State has some form of Arbitration within the State and can give a common rule which will cover everyone not covered by a Federal Arbitration Award ... Our districts also use the State which is beneficial in dealing with casual work ... Whatever this sounds like it is not involved and quite simple in the effect when one is used to the procedure.... ${ }^{31}$

Of the judges and the quality of judicial intervention, Trevelyan wrote,

Speaking generally I am inclined to the opinion that all judges when first appointed to Arbitration duty have an accepted and well defined class consciousness which carries a subconscious class bias. Early environment and education deeproot these tendencies. It is generally accepted that the master class is top dog, and has the right to do - well almost anything he likes as long as it is legal ... I find that usually after the first year or so their experience develops within them an admission that employers are frequently hardhearted and unfair and mostly determined to maintain the ascendency [sic] they have hitherto held unchallenged, and gradually these judges develop a sense of sympathy and almost as an outgrowth of nausea and determination to give the workers interest greater practical consideration. ${ }^{32}$

From the time of his appointment to the reconstituted Commonwealth arbitration court in 1926, Judge George James Dethridge heard most disputes involving the entertainment industry (including the Musicians' Union), ${ }^{33}$ thus acquiring, over the period of his tenure, a comprehensive knowledge of the industry's special features and requirements. Described by Trevelyan as "essentially a fair minded and reasonable man,"34 Dethridge is assessed as a judge as being "a cautious but flexible conservative," and is said to have had some sympathy for the position of the working man, offsetting the bias of class and education noted by Trevelyan. ${ }^{35}$ At another time Trevelyan commented of the judge, "I know his Honor is sympathetic towards the musicians but he must take a common sense view point and deal with facts as he finds them." ${ }^{36}$

\section{Growing Hostility in Evolving Policy on Foreign Musicians}

At the Annual Conference of the federal body of the MUA held in Melbourne in November 1923, a resolution was passed to redraft the federal Rule Book (last published in 1914) in order to consolidate rules added in the intervening years. ${ }^{37}$ At the Conference in November 1925, with the revised rule book already

\footnotetext{
${ }^{30}$ Trevelyan was General Secretary from 1924 until his death in September 1935, with prior experience as Secretary of the South Australian District. Letter, Trevelyan to F. Dambman, General Secretary, (British) Musicians' Union, 25 January 1935, MUA NBAC E156/2/4(i).

${ }^{31}$ Letter, Trevelyan to Dambman, 25 January 1935, MUA NBAC E156/2/4(i).

${ }^{32}$ Ibid.

${ }^{33}$ Trevelyan wrote, "Chief Judge Dethridge takes all the cases in the Entertainment Industry." It was Dethridge who presided over and ruled on the challenge to the MUA federal rules in 1929 to be discussed below. Source as for note 31.

${ }^{34}$ Ibid.

${ }^{35}$ Ian G. Sharp, "George James Dethridge," in Australian Dictionary of Biography Vol. 8, eds. Bede Nairn and Geoffrey Serle (Carlton: Melbourne University Press, 1981), 293.

${ }^{36}$ Letter, Trevelyan to A.A. Greenbaum, Secretary MU San Francisco, 6 December 1932, MUA NBAC E156/2/4(i).

${ }^{37}$ The General Secretary Cecil Trevelyan is credited with the achievement of a "uniform set of rules and one Federal award." (Smith's Weekly n.d. [1931?], Press cuttings 1927-29, MUA NBAC Z401 Box 12); a statement to that effect appears in Rules of the Musicians' Union of Australia, 1925, MUA NBAC N93/476.
} 
registered, ${ }^{38}$ the meeting determined to work towards new rules. ${ }^{39}$ This decision set in motion a process of rule formulation and amendment that occupied the rest of the decade. It was not a trivial decision since, whereas the 1925 rule book reflected the organization's benign origins as a benevolent society and employment agency, ${ }^{40}$ the rule book that took shape from 1925 to the end of the 1920 s effected a transformation of its culture into an oligarchic bureaucracy, with all that implies in terms of centralized power and devaluation of individual freedoms.

Up to the 1920s, the membership rules of the federal body were more concerned with outlining general terms of compliance with the requirements of the arbitration legislation than with formulating specific terms of eligibility, since applications for membership were dealt with by the individual Districts, which set their own terms and conditions under State registration. The 1921 Rules of the NSW District of the Union, for example, while treating "visiting professionals" not unreasonably as a separate category, nonetheless allowed for fixed-term membership of six months' duration, and for the possibility of such musicians becoming "ordinary members" upon payment of an additional fee. This provision at least acknowledged the reality that some visitors, given favorable professional opportunities, might choose to remain in the country. In the revision of 1927, section 4 ("Objects") reiterates the federal body's intention "to oppose, by all constitutional methods, the admission into Australia from overseas of professional musicians under contract or agreement to contract after arrival in Australia," although the exclusionary thrust of the revisions as they take shape is clearly aimed at all foreign musicians, contracted or not. "We feel that any employment offering should be the prerogative of the native born," stated Federal President and NSW District Secretary Frank Kitson, promoting the Union's latest embargo against foreign-born musicians in $1949 .{ }^{41}$

How is such an attitude to be characterized given that the country was legislatively committed to a racist immigration policy and that discrimination on the basis of country of origin would have a broad base of social support? Is it ultra-nationalism? Or can it be viewed more opportunistically as an attempt to consolidate political power by mobilizing "different coalitions around different issues"? ${ }^{42}$

Insofar as the Union's attitude towards foreign musicians was driven, and certainly sanctioned, by the racist sentiments of an all-White, all-British Australia as expressed in the Immigration Restriction Act of 1901, it was no different from that of any other Australian Union of the time. Indeed, Julia Martinez has written that "'White Australia' continued as the dominant ideology of Labor unionists." 43 But there is also a paradox here, for although the MUA organized its discriminatory anti-foreign resolutions around the slogan "keep orchestras British," British-born or English-speaking musicians from Commonwealth countries were equally unwelcome.

From the mid- to late-1920s, the MUA found itself engaged in particularly hostile exchanges with the English Union over its attitude towards British musicians. It was not so much its campaign of opposing imported bands or excluding foreigners, since the English Union pursued similar goals, ${ }^{44}$ as the inclusion of British musicians in the category of "foreigners." "Treat the American, the Italian and the German as you will," wrote the editor of Melody Maker, a British trade journal, to Trevelyan, “... but we Britishers look

\footnotetext{
${ }^{38}$ Rules of the Musicians' Union of Australia, 1925, MUA NBAC N93/476.

${ }^{39}$ Minutes of the Annual Federal Conference, November 1925, MUA NBAC E156/6/3.

${ }^{40}$ For a summary of the Union's early history, see Arthur, "Industrial Relations," 348.

${ }^{41}$ In November 1949 the Union resolved to restrict membership of orchestras to 90 percent Australians and 10 percent British people who had lived in Australia for ten years. Minutes of the 1948 Annual Federal Conference, p. 8, MUA NBAC E156/6/7. Kitson quote is Sunday Sun, 23 April? 1949, Press cuttings 1938-52, MUA NBAC Z401 Box 13.

${ }^{42}$ Macintyre and Mitchell, "Introduction," 12.

43 Julia Martinez, “Questioning 'White Australia': Unionism and 'Coloured' Labor, 1911-37,” Labor History 76 (May 1999$)$ : 1.

${ }^{44}$ Cyril Ehrlich, The Music Profession in Britain since the Eighteenth Century, A Social History (Oxford: Clarendon Press 1985),

216-17.

${ }^{45}$ Letter from the Joint Editor of Melody Maker to Trevelyan, 12 June 1929, MUA NBAC E156/2/4(i).
} 
upon the Commonwealth, by birthright, as being another home, should we have to go there, and you yourselves always literally talk of a journey to England as 'going Home,' knowing full well that all civic privileges are yours because you are in every way members of the same kinship."

Trevelyan was at pains to point out to his English Union colleagues that MUA rules privileged British musicians within the foreigner class, but the English objected to the requirement that British musicians should reside in Australia for six months without working in the profession before becoming eligible for membership or pay the higher overseas musicians' fee of $£ 21$, observing, that "there are many Australians in London and no bar is put up against them so long as they don't undercut our terms. Our people are of the opinion that no bar should be put up against our members going out from the Motherland to distant parts of the Empire and vice-versa, always subject to local terms and conditions being observed."46 The argument raged on through the 1930s in letters and in the press, with the MUA adamant and the English MU asserting that the policy was "anti-British" and likely to precipitate a change of policy in Britain towards Australians seeking work there (which it eventually did). ${ }^{47}$

Various sections of the Commonwealth Conciliation and Arbitration Act allowed for the rules of a registered organization to be challenged if oppressively administered, but to do so presumed a knowledge on the part of the claimant not only of the Constitution and the Act, but, in the case of the MUA, of a federal rule book - which by 1929 comprised some 96 pages, 92 sections and their subsections - and of the rules of the District in which a claimant was a member-89 sections with their sub-sections in the case of the NSW District. Challenges involving rules and appeals to the law were necessarily argued by counsel, a significant expense, and it is not surprising that few were lodged by individual members. However, in February 1929, a summons was issued by the Theatrical Proprietors and Managers Association of Australasia for the suspension or cancellation of awards on various grounds, one being that the Union had adopted improper rules.

Six rules relating to the employment of foreigners in orchestras as developed in the second stage of rule revision (between December 1926 and November 1929) were challenged, among others. ${ }^{48}$ Ultimately, the judge's objection to these rules was neither ethical nor ideological but only concerned the wording, which potentially involved complying musicians in a breach of their contracts. The judge concluded that "there is an industrial struggle for life between similar classes of employees in different countries, and defensive devices are inevitable," finding the rules to be clear in intent "although not very precisely expressed." Summing up, he remarked, "Several of the foregoing rules have been objected to on the ground that they confer discretionary powers on the union, or its various executive organs, which may be improperly used ... But some such powers must be allowed, and rules embodying these powers are not bad merely because they are capable of being directed to bad ends." 49

Challenges by individuals could only be argued in the State tribunals as individual workers had no status before the Federal Court. ${ }^{50}$ One such challenge was issued in 1928, when two Italian musicians who

\footnotetext{
${ }^{46}$ Letter, General Secretary, (British) MU, to Trevelyan, 21 September 1925, MUA NBAC E156/2/4(i).

${ }^{47}$ As for note 45. Hostile articles appeared in Era (January 1928) and Melody Maker (November 1929), to which Trevelyan responded in an article in the MUA's journal, The Professional Musician, September 1929, 10 and 12, MUA NBAC E156/11/1.

${ }^{48}$ Only those sections of the judgment dealing with restrictions on foreigners in orchestras were reported in the press (Evening News 27 May 1929; Sydney Morning Herald [SMH] and Daily Guardian [DG] 28 May 1929), Press cuttings 1927-29, MUA NBAC Z401 Box 12 .

${ }^{49}$ The judgment may be found at CAR 27 (1928-29), 1141-45.

${ }^{50}$ This situation has been read in two ways: legislatively ("The act favours collective bargaining. Workers individually have no status before the Court... ." [Source as for note 31]) and politically ("The feminist analysis of bureaucracy sees it as purporting to be a politically neutral discourse — of efficiency, rules, roles and procedures — which has the effect of depowering individuals... ." Diane Kirkby, "Arbitration and the Fight for Economic Justice," in Macintyre and Mitchell, 347). For a discussion of the complications
} 
had come to Australia under contract to the Gonsalez Opera Company applied to the court for a declaration of their entitlement to membership. The matter was heard in the NSW Industrial Commission, with plaintiffs and Union represented by counsel. At issue were not only the complications arising from the extent of the tribunal's jurisdiction over a federal union with a state branch registered under the laws of the State, but the relationship of various contracts binding the musicians (that between themselves and their employer, and that between the employer and the union). ${ }^{51}$

Frank Kitson, in opposing the application in his role as Secretary of the NSW District, informed the Commission that, as they could not speak English, the musicians could not obey an orchestral conductor. "A conductor couldn't start them," Kitson is reported to have said [Daily Guardian, June 12, 28], "and if he could he wouldn't be able to stop them,"--lively copy, perhaps, and a fair representation of the Union's position, but a distortion of what was, in fact, an extended discussion of the extent to which the musicians' inability to speak English would impact on rehearsals and performances. In the end, however, the court was unable to uphold the appeal because of limitations in its powers. Mitchell and Rosewarne also admit, "in these cases [of complaints about inability to secure admission to a union], the law has not adopted a strongly interventionist role ... the courts generally will not interfere with the prescribed criteria of membership, no matter how unfair or arbitrary.",52

When one of the plaintiffs, who had not worked professionally as a musician in the meantime, reapplied for membership in November 1932, Kitson wrote to Trevelyan with a revealing opportunism,

Doubtless, my District would have continued to debar him from the Union, but he has made application to become a naturalised citizen. On producing proof of this application and with the knowledge that such application was about to be granted in a few weeks, my Committee thought it better to admit him at $\$ 21$ than to charge a naturalised subject $£ 21$ or admit him at $£ 5 / 5 /$. It was obvious that the grounds for his nonadmittance, viz. "foreigner" were about to be removed. ${ }^{53}$

One of the touted attributes of the arbitration system was that it elevated industrial disputation to a plane of rational discourse, but darker elements of prejudice and mean-spiritedness lie not too far beneath the surface.

\section{The Vexed Question of Skill}

It is difficult to adjudicate issues of skill or to articulate those elements of music performance practice that are passed on by example and consolidated over generations. As Judge Dethridge remarked, "If this court attempted to determine the rate of pay for artistry it would find itself in a hopeless mess." ${ }^{, 54}$ According to Kitson, Italian musicians who visited Australia with touring opera seasons of the 20th century brought nothing that could not be supplied or surpassed by local players: "That we have the players here is instanced by the last J. C. Williamson grand opera season [of 1924], when imported Italian musicians were relegated by an Italian conductor to a lower position, and Australians placed in advance of them." testing the truth of Kitson's assertion as the listing of musicians in the 1924 season souvenir program is alphabetical by name and not by orchestral desk, but of the four imported Italians (in an orchestra of fifty),

\footnotetext{
around the legislative protection of individuals under arbitration, see Mitchell and Rosewarne, 197-202 and Alan Boulton, "Government Regulation of the Internal Affairs of Unions," in Cole, 231-2.

${ }^{51}$ The first stage of the appeal was reported in DG, 12 June 1928 and $S M H, 13$ June 1928 (Press cuttings 1927-29, MUA NBAC Z401 Box 12) and by Kitson in The Professional Musician, September 1928, 18-19, MUA NBAC E156/11/1. The transcript of the hearings may be found at "Oyoyly vs Musicians' Union," State Records NSW, 6/1433, "1928 Industrial M-R." For an account of the Fuller-Gonsales tour, see Alison Gyger, Opera for the Antipodes (Paddington, NSW: Currency Press, 1990), Ch. 20.

${ }^{52}$ Mitchell and Rosewarne, 196.

${ }^{53}$ Letter, Kitson to Trevelyan, 11 November 1932, MUA NBAC Z401 Box 5.

54 "High Rates for Radio Musicians," undated, unattributed clipping, Press cuttings 1927-29, MUA NBAC Z401 Box 12.

${ }^{55}$ Daily Telegraph, 2 March 1928, Press clippings 1927-29, MUA NBAC Z401 Box 12.
} 
one, a double bass player called Luigi Ricci-Bitti, could claim that he had worked professionally and consistently in itinerant opera companies throughout Europe and southeast Asia, ${ }^{56}$ an experience unlikely to be matched by even the best of Australia's players. A shortage of good players in particular instrumental categories - woodwinds and double basses, for example — was frequently mentioned in the press in the late nineteenth and early twentieth centuries. ${ }^{57}$

Until the establishment of the Elizabethan Theatre Trust in the 1960s, there was no permanent orchestra available to play for opera or ballet in Australia. Instead, "scratch" ensembles were "somewhat hastily organised" from the best local talent available, ${ }^{58}$ and whether or not the best musicians available were always the best is an open question. Trevelyan admitted, "We have the five instruments of the class and quality desired, but our men are earning more in permanent billets and will not play for the money offered."59 The 1924 Williamson Grand Opera Season is recorded as having included 211 performances of 17 operas in 28 weeks, with a different opera on each night of the week and minimal rehearsal time, ${ }^{60}$ and although orchestras rarely attracted comment in newspaper reports of operatic performances, there is enough to give a sense of the pressures of inadequate rehearsals and unfamiliarity with a constantly changing repertoire.

In the same year, the Union asked the Industrial Registrar to adjudicate on the question of whether the importation of Harry Yerkes' (white) American band to play at the Wattle Path dance palace in Melbourne constituted discrimination under the Award by threatening the jobs of local musicians ("Discrimination means preferring non-members to members all other things being equal" [my emphasis]). The Registrar declined to endorse the Union's argument that it did, accepting instead the entrepreneur's argument that Australian musicians were unable to "get that rhythm that is essential in the dancing halls nowadays." The employer argued that public taste was driving his commercial interests: "We boosted an Australian Band when the Americans were here but the public wanted an American band. We tried very hard to keep the Australian orchestra but public opinion was against it. As a matter of fact our own men were unable to get the same rhythm as the Americans."

The Registrar concluded, "My view is that it is not discrimination as far as the award is concerned, at the same time it is going to be a very disastrous state of affairs for our own citizens if this kind of thing is going to spread throughout the country." ${ }^{61}$ The Union argued that the problem was indeed spreading throughout the country: "American musicians arrived here in large numbers and supplied dance bands. In almost every case Australians were displaced and ... the novelty caught on and became a serious problem .... The Americans who came here were paid over the Award rate and displaced Australians ...." ${ }^{, 62}$ The President of the American Federation of Musicians, being appealed to, did not share the Australian's view that the situation was critical: "As I take it that organizations composed of members of the Federation who visit Australia only do so for a limited time and are employed for the reason that they are considered an attraction, the matter will adjust itself when their attractiveness has passed."63

The matter at issue was, as the Secretary to the Prime Minister's Department wrote to Trevelyan in May 1928, "largely one of fact, i.e. whether it is possible to obtain in Australia musicians whose training and experience render them suitable for employment in orchestras" ${ }^{\prime 64}$ or whether, as was unsympathetically

\footnotetext{
${ }^{56}$ Tempo (May 1949): 6.

${ }^{57}$ See Suzanne Cole and Kerry Murphy, "Wagner in the Antipodes," Wagnerspectrum (Bayreuth: Richard-Wagner Museum, 2008), http://www.wagnerspectrum.de/aktuell.html.

${ }^{58}$ Gyger, 207.

${ }^{59}$ Letter, Trevelyan to General Secretary, (British) MU, 7 March 1928, MUA NBAC E156/2/4(i).

${ }^{60}$ Gyger, 250.

${ }^{61}$ This quotation and those in the previous paragraph are from the transcript of the hearing, 21 August 1924, MUA NBAC E156/8/7.

${ }^{62}$ The Professional Musician, September 1929, 10, MUA NBAC E156/11/1.

${ }^{63}$ Letter, President of the American Federation of Musicians to Trevelyan, 4 June 1924, MUA NBAC E156/2/4(i).

${ }^{64}$ MUA NBAC E156/2/6(ii).
} 
inferred in a contemporaneous article by a British music magazine, "Australian musicians needed protection because of their lack of ability." 65 The recurring argument was not about numbers but about perception: "the effect [of the importation of six 'key instrumentalists'] would be ... to foster a belief in the scarcity of talent here and migration would be intensified." ${ }^{\prime \prime 6}$ The Union consistently maintained its position that Australian musicians could supply what was needed and refused to differentiate skill within its general protectionist argument against foreign musicians. As the Sydney Morning Herald reported on March 17, 1928, "No objection was made to the employment of specially skilled foreigners, but Australians should come first." Pursuing the same argument twenty-one years later, in 1949, Frank Kitson defended the Union position, "Our action [in implementing yet another embargo against foreigners in the Australian Broadcasting Commission's (ABC) orchestras] is no different from that of an industry seeking a tariff to keep out goods from overseas." 67

The ongoing debate intensified as Australia's orchestral culture began to achieve permanence in the orchestras associated with the ABC. Repeated complaints by visiting artists—some extremely colorful—over the standard of orchestral music-making in the decades of the 1930s and 1940s were simply dismissed by the Union as unpatriotic. ${ }^{68}$ But the Union's uncompromising line on the issue was steadily seen as an impediment to progress, even by unpartisan observers: "It seems that the union, while engaged in the praiseworthy task of safeguarding the industrial interests of its members, has also become a protector of mediocrities and a drag on musical progress," wrote a staff correspondent of a major Sydney newspaper in 1944. ${ }^{69}$ Other voices were more forceful. Competition is healthy, opined Richard Goldner, a viola player who was refused Union membership when he arrived in Australia as a refugee in 1939 and was thus unable to take up an offer of a "leading position" in an ABC orchestra, and admission to the Union should be based on a minimum standard, not national origin. ${ }^{70}$ Captain H. E. Adkins, Director of Britain's prestigious Royal Military School of Music and engaged on a short-term contract as the first conductor of the ABC's military band, stated as his opinion that the MUA would "unless curbed in some way, kill musical life in this country." $" 71$

Unfortunately, or so Martin Buzacott argues, the legislators and politicians involved in resolving these issues into policy were not always well placed to make judgments: "for politicians ... the emotional power of the 'Australians first' and 'secure employment' arguments were compelling in a community in which everybody wanted cultural excellence but very few could notice the difference between, say, the artistic standards of one professional cellist compared with another." ${ }^{, 72}$

\section{The Quest for Legislative Protection}

In the early 1920s, anxieties about foreign musicians attached themselves to the importation of American bands for dancing, as is reflected in Trevelyan's letters to the Secretaries of English-speaking

\footnotetext{
${ }^{65}$ The Melody Maker, November 1928, reported in The Professional Musician, September 1929, 12, MUA NBAC E156/11/1.

${ }^{66}$ Letter, Frank Kitson to Charles Moses, Chairman of the Australian Broadcasting Commission, 4 August 1939, MUA NBAC E156/2/2(ib).

67 "How Ban on Oversea Players Will Affect Music Here," undated, unattributed clipping [1949?], Press cuttings 1938-52, MUA NBAC Z401 Box 13.

${ }^{68}$ For example, visiting pianist Ignaz Friedman brewed up a storm when he commented publicly, "Some of your brass players ought to be sent to the Far East to break down the walls of Jericho." "Pianist Slates A.B.C. Standard of Music," undated, unattributed clipping [1943?], Press cuttings 1938-52, MUA NBAC Z401 Box 13.

${ }^{69}$ SMH, 24 March 1944, Press cuttings 1938-52, MUA NBAC Z401, Box 13.

${ }^{70}$ SMH, 3 April 1944 and 10 April 1946, Press cuttings 1938-52, MUA NBAC Z401 Box 13.

71 "A report to the Australian Broadcasting Commission [1934]," National Archive of Australia (NAA) SP 1538/2 [Box 46] cited in Martin Buzacott, The Rite of Spring: 75 Years of ABC Music-Making (Sydney, ABC Books, 2007), 27 and 410 n.15.

${ }^{72}$ Buzacott, 227.
} 
foreign unions from early 1925. Beginning at that time, the MUA undertook "to secure legislation that will prevent the influx of any persons whose admission to Australia may be detrimental to Australians." ${ }^{, 73}$ It was not the only Australian union to attempt to control or prevent, through legislation, foreign participation in the labor force; Andrew Markus identifies more than thirty separate Acts in Queensland alone between 1901 and 1920 designed to restrict the occupational freedom of foreign workers. ${ }^{74}$

Circular letters were sent to Members of the Commonwealth Parliament and the Union had a Bill drafted for an Act restricting the importation of immigrant musicians under contract, which it attempted to have brought before the House, ${ }^{75}$ but the issue lacked political purchase and the legislation failed to pass. ${ }^{76}$ The Union tried to argue that imported musicians fell under the tighter provisions of the Contract Immigrants Act (the Amending Immigration Act) of 1905, whereby employers wishing to bring in laborers under contract had to gain approval from the Minister of External Affairs, and pressed for similar controls to be introduced for foreign musicians. But the government maintained that the restrictions of the Act applied only to manual labor and thus did not apply to music. ${ }^{77}$ The Union tried again in May 1928, but again the government declined to take "so drastic a step as the prevention of the entry into Australia of bands of foreign musicians ... The international aspect of the matter must be considered and it is almost certain that action such as you suggest would indubitably result in repercussions in other countries, particularly America." ${ }^{, 78}$ It was, as the Minister of Trade and Customs acknowledged, a situation "bristling with difficulties." little but rail against the public taste for American bands and insistently refute the notion that only American musicians could play jazz. ${ }^{80}$

However, when, in 1928, Hoyts employed an imported orchestra of thirty Italians for the opening of the luxuriant new Regent Theatre in Sydney, and J. C. Williamson concurrently imported twelve Italians for the Williamson-Melba Grand Opera Season (breaking its negotiated agreement with the Union for five), the Union was able to link its feelings of resentment to general public concerns about Italian migration, for although southern Europeans were not specifically excluded under the terms of the Immigration Restriction Act of 1901 and thus were entitled to citizenship and union membership, they were regarded as racially inferior and subjected to prejudicial treatment. Trevelyan painted migration as a threat to the union movement as a whole: "Thousands of foreigners - in all callings — are being brought to this country and Australian workers generally consider there is an organised attempt to swamp the market, break Unionism and install cheap labour." 81

Italians made up the largest numbers of non-British or "alien" immigrants to Australia in the 1920s with some 23,233 arriving in Australia between 1922 and $1930 .^{82}$ As the decade progressed and unemployment grew, this "influx" became a focus of public discussion and resentment. Accordingly, the government introduced various restrictions and controls on Italian migration: quotas, visas, landing fees or guarantor requirements, or nominations by close relatives already resident in Australia. In fact, assisted

\footnotetext{
${ }^{73}$ Clause ( $\mathrm{t}$ ) of the Objects of the MUA, was added to the 1927 Rule Book, 13, MUA NBAC N93/477A.

${ }^{74}$ Andrew Markus, Australian Race Relations 1788-1993 (St Leonards: Allen \& Unwin, 1994), 120.

${ }_{76}^{75}$ Letter, Senator Burford Sampson to Trevelyan, 10 May 1926, MUA NBAC E156/2/6(ii).

${ }^{76}$ The Professional Musician, September 1929, 10, MUA NBAC E156/11/1.

${ }^{77}$ The argument over the applicability of the Contract Immigrants Act was on-going. See, for example, Minutes of the Federal Conference, 1923, MUA NBAC E156/6/2; "Musicians Union-Importation of Bands-Contract Immigrants Act," Minute Paper, Attorney-General's Department, Commonwealth of Australia, 18 May 1937, NAA File A432, 1937/383.

${ }^{78}$ Letter, Secretary to the Prime Minister's Department to Trevelyan, 23 May 1928, MUA NBAC E156/2/6(ii).

${ }^{79}$ Letter, Minister for Trade and Customs to Trevelyan, 14 March 1930, MUA NBAC E156/2/6(ii).

${ }^{80}$ As, for example, W.H. Lamble to General Secretary, (British) MU, 13 July 1939: "It is a curious anomaly ... that British people think more of the foreign article than they do of their own production." MUA NBAC E156/2/2(xi).

${ }^{81}$ Circular letter, Trevelyan to Foreign Musicians Unions, 9 January 1928, MUA NBAC E156/2/4(i).

${ }^{82}$ Gianfranco Cresciani, "Italian Immigrants 1920-1945," in The Australian People: An Encyclopedia of the Nation, Its People and Their Origins, 2nd ed., ed. James Jupp (New York and Oakleigh, Vic.: Cambridge University Press, 2001), 500.
} 
British migration far exceeded Italian, but this did not alter public perception. Arnaldo Cipolla, an Italian writer who visited Australia during the 1920s, declared that although the total number of Italians arriving in Australia in 1924 was 4,000, as against about 88,000 British, "to read the newspapers and the parliamentary reports of the day, you would have thought that Italy was about to invade the Commonwealth." $\$ 3$

Though one could argue that the Union's assessment of the Italian musical "influx" was similarly overstated, ${ }^{84}$ it was an issue with significant rhetorical and political potential. The Union could, for example, join other voices in asserting that the Italians were undermining wages and working conditions (untruthfully in the case of contracted musicians, since compliance with Australian Awards was written into negotiated contracts and sometimes the Italian musicians were actually paid more than their Australian counterparts). ${ }^{85}$ Or, it could support the Theatrical Employees' Union in its threat of industrial action when it was found that the Italian chorus girls in the 1928 Williamson-Melba Grand Opera Season were also being paid more than the Australian girls (an irony apparently lost on Union officials). ${ }^{86}$

On March 28, 1928, W. M. Hughes, maverick politician, former Prime Minister, and avid proponent of a free British White Australia, made a speech at the National Party conference in which he attacked the government's policy on Italian migration: "We believe in a White Australia," he intoned, "and a British White Australia at that." ${ }^{87}$ Hughes referred to the fact that he had recently introduced a deputation of Australian musicians to the Prime Minister, Stanley Melbourne Bruce, to protest against the importation of foreign musicians. ${ }^{88}$ The deputation was undoubtedly prompted by the Union's lack of success in preventing the importation of the Hoyts Italian orchestra.

The MUA's efforts were rewarded with limited success in July 1928 when the Department of Homes and Territories finally announced that it was introducing a form of licencing for entrepreneurs wishing to import musicians for pit bands and orchestras, ${ }^{89}$ though it is likely less the result of the Union's petitions than of a sexual scandal involving a "negro" stage band that had occurred in Melbourne in March 1928, since the licences were primarily intended to exclude colored musicians. ${ }^{90}$ Amongst various requirements, the prospective employer was to be asked to disclose whether application had been made to the Union for the class of performer required and whether there was any special reason for employing a foreigner instead of a local musician. ${ }^{91}$ Though the Union was able to announce to its members, in September 1929, that "there are no American or Italian orchestras, nor orchestras of any foreign nationality, here now"

\footnotetext{
${ }^{83}$ Stephanie Lindsay Thompson, "Italian Migrant Experiences of Australian Culture (1945-1970): Historical Background," in Australia, The Australians and the Italian Migration, ed. Gianfranco Cresciani (Milan: Quaderno di Affari Sociali Internazionale, 1983), 30 and n. 11. From "White Australia. The East and the West," SMH, [?.?.1928]: "It was easy to imagine that after some years of this kind of penetration, Australia and Canada would not retain their traditional aspect as British dominions." Press cuttings 192729, MUA NBAC Z401 Box 12.

${ }^{84}$ Of the $c .54$ Italian musicians who were brought to Australia in connection with the four major events under discussion in this article, not more than half a dozen seem to have succeeded in remaining in the country and joining the Union.

${ }^{85}$ See, for example, transcript of the hearing in the Principal Registry of the Commonwealth Court of Conciliation and Arbitration, 21 August 1924, MUA NBAC E156/8/7.

${ }^{86} D G$, 16 June 1928, Press cuttings 1927-29, MUA NBAC Z401 Box 12. The Australians received redress.

${ }^{87}$ SMH, 29 March 1928, Press cuttings 1927-29, MUA NBAC Z401 Box 12.

${ }^{88}$ The deputation was reported in SMH, 17 March 1928, Press cuttings 1927-29, MUA NBAC Z401 Box 12. It was supported by the leader of the opposition Labor party, Matthew Charlton and included James Scullin, who succeeded Stanley Bruce as (Labor) Prime Minister in 1929.

${ }^{89}$ SMH, 21 July 1928, Press cuttings 1927-29, MUA NBAC Z401 Box 12.

${ }^{90}$ SMH, 29 March 1928, Press cuttings 1927-29, MUA NBAC Z401 Box 12; Letter, Secretary to the Prime Minister's Department to M. Charlton, MP [Member of Parliament], 11 July 1928, MUA NBAC E156/2/6 (ii): "The firms ... are accordingly being advised that in connection with the administration of the Immigration Act, under which power could be exercised if necessary to prohibit the landing of any person whose admission had not been authorised by the Minister for Home and Territories, application should to be made to that Department and the Minister's approval obtained before arrangements are made in future to introduce into Australia foreign musicians under engagement to perform in orchestras or bands."

${ }^{91}$ SMH, 21 July 1928, Press cuttings 1927-29, MUA NBAC Z401 Box 12.

92 The Professional Musician, September 1929, 12, MUA NBAC E156/11/1.
} 
had more to do with the worldwide economic depression - it was to some extent a Pyrrhic victory, as the Minister had declined to make the Union a party to the decision-making process, retaining his discretionary power to "consider each case on its merits." 93

\section{Conclusion}

This article has identified the issue of the importation of foreign musicians as situated at the nexus of a conflict between the Musicians' Union and various theatrical entrepreneurs. Given that "conflict is essential to the survival of both parties" in the dialectic of work-place relations, ${ }^{94}$ conflict over the issue of foreign musicians can be viewed as an inevitable outcome of a set of conditions that prevailed in the industrial relations system in the 1920s. But to say that would be to ignore the role of systemic racism and generalized xenophobia in validating the Union's covert policy of discrimination against individual foreign musicians, a policy that prevailed for several decades with degrees of institutional and political support.

In her article on "Union Strategy: A Gap in Union Theory," Margaret Gardner contends that "Unions behave in characteristic ways, but not all act alike. ${ }^{95}$ However, at least with regard to its efforts to financially penalize, delay, limit, disenfranchise, and ultimately exclude "oversea musicians," whether resident or visiting, from membership, the Union's strategies show features in common with those of other unions engaged with foreign labor. The determination that only financial British and naturalized British subjects were entitled to vote in Union elections is reminiscent of the withholding of votes from supporters of Chinese immigration within the furniture trade union in $1880 ;{ }^{96}$ British preference quotas recall similar quotas introduced against the Italians in the Queensland sugar-cutting industry in the $1920 \mathrm{~s} .{ }^{97}$ Deputations to the Prime Minister, mass mailings to Members of Parliament, appeals to sympathetic parliamentarians, and approaches to Ministers with appropriate responsibilities were all strategies that have parallels in other industries. ${ }^{98}$ Indeed, one might argue that the Union's promotion of the normative white British male mirrored the arbitration system's benchmark preferencing of the white Australian male wage-earner.

Notwithstanding this larger truth, this article has argued that, because of the distinctive features of the music industry in Australia, the issue of foreign musicians became a "frontier of control" between the Union and entrepreneurs that was disputed and mediated by the regulatory conventions of Australia's distinctive, State-sponsored conciliation and arbitration system. Not only was that system highly bureaucratic, but the culture it generated had a deeply embedded emphasis on the making of rules and the containing of conflict within a regulatory framework. ${ }^{99}$

Within the resultant organizational culture of the MUA, the exercise of power and control through the legalism of the minutiae of the rules was clearly more important than the fate of the individuals who found themselves caught up in it. As Kathy Ferguson has written, "Bureaucracies proliferate rules as means to their ends, and emphasize adherence to established procedures in order to obtain standardized, reliable progress toward these ends. But the situation is such that the bureaucrats come to see adherence to the rules as itself

\footnotetext{
${ }^{93}$ Letter, Assistant Secretary, Home and Territories Department to Trevelyan, 3 September 1928, MUA NBAC E156/2/6(ii).

${ }^{94}$ Deery and Plowman, 45.

${ }^{95}$ Margaret Gardner, "Union Strategy: A Gap in Union Theory," in Australian Unions: An Industrial Relations Perspective, 2nd ed., eds. Bill Ford and David Plowman (South Melbourne: The Macmillan Company, 1989), 49.

${ }^{96}$ See Andrew Markus, "Divided We Fall: The Chinese and the Melbourne Furniture Trade Union 1870-1900," Labor History 26 (May 1974): 1; Rules 1929, section 41c (amended Dec. 1928), 41, MUA NBAC N93/478.

${ }^{97}$ Markus, Australia's Race Relations, 149 and Cresciani, 502; on the Union's quotas, see, Rules 1927 section 4 (v) (a) and (b), registered December 1927, 14, MUA NBAC N93/477A.

${ }^{98}$ See Markus, "Divided We Fall," 5.

${ }^{99}$ Deery and Plowman $(12,19)$ cite different theoretical approaches that view these as defining features of the Australian system.
} 
the goal. Thus the function of the bureaucracy comes to be equated with its purpose." ${ }^{\prime 100}$ Feminist scholars have critiqued the masculinist features of the arbitration culture, characterizing it as a "rational, bureaucratic, hierarchical and authoritarian system of power allocation," further observing that "male workers have used the authority of the system to enhance their own position vis-à-vis that of competitive labor, women and juniors." 101

It is a truism that Unions operate for the benefit of their membership, but policy formulation and rulemaking is imagined and articulated by very few voices. To some extent this is also an outcome of the system, for while registration gave legal status and recognition to unions, the system devalued participatory styles of union organization, "because courtroom methods of operation encouraged specialized skills which did not necessarily depend on interaction with rank and file members." 102 Despite elaborately democratic governance formulae, though presumably with the implicit consent of the membership, the formation of Union policy over foreign musicians was nominally driven by the small cohort of office-bearers that constituted its Federal Council, but actually by an even smaller oligarchy of two or three long-serving, full-time, salaried officials.

In terms of its culture of rule-making, the arbitration system may be seen as a shaping influence on the organization and a mechanism for legalization of its values and policies. Most damagingly, the system's endorsement of discretionary powers for the Union in the implementation of its rules, and the court's reluctance to interfere with a Union's prescribed criteria of membership, allowed the system's espoused values of equity and fairness to be subverted so that a potentially legitimate industrial concern over the largescale importation of bands or orchestras of foreign musicians could become a site for the prejudicial treatment of individuals.

\section{Acknowledgements}

Primary source research for this article is based on the archives of the Musicians' Union of Australia, Noel Butlin Archive Centre, Australian National University, Canberra (NBAC MUA). My thanks go to the Centre's staff for their courtesy and helpfulness, to Monash University for travel assistance, to Professors Andrew Markus, Alistair Thomson and Kerry Murphy for critical input and to Jonathan Dreyfus for editorial expertise.

\footnotetext{
${ }^{100}$ Kathy E. Ferguson, The Feminist Case Against Bureaucracy (Philadelphia: Temple University Press, 1984), 9 and n. 15.

${ }^{101}$ Kirkby, 347.

102 Markey, 170.
} 


\begin{abstract}
In September 1929, the General Secretary of the Musicians' Union of Australia announced in the official journal, "there are no orchestras of any foreign nationality here now ... the fight is over," an extraordinary statement given that the non-indigenous musical traditions of this former British colony are entirely transplanted. The proximity of the date to the advent of sound films suggests a causal relationship, but the facts are more complex. The issue of foreign musicians became the site of a struggle for control of the labor market, a struggle rooted in the institutionalized racism of the Immigration Restriction Act of 1901 (the infamous so-called White Australia Policy), legitimized by the distinctive structures of the arbitration system and sanctioned by legal recognition of trade union autonomy with regard to membership regulation. This article examines the evolution and consequences of the MUA's policy on foreign labor through the 1920s and its efforts to mobilize legislative support by appeals to popular concerns.
\end{abstract}

